\title{
THE CHALLENGES FOR LOGISTICS IN THE ASPECT OF INDUSTRY 4.0
}

\section{doi:10.2478/mape-2018-0070}

Date of submission of the article to the Editor: 05/2018

Date of acceptance of the article by the Editor: 07/2018

\author{
PhD., Eng. Marzena Kuczyńska-Chałada \\ PhD., Eng. Joanna Furman \\ Msc., Roksana Poloczek \\ Silesian University of Technology, Poland
}

MAPE 2018, volume 1, issue 1, pp. 553-559

\begin{abstract}
Logistics and forecasting of changes should be permanent elements of logistic activity. This requires the observation of new conditions for logistics as well as its multifaceted analysis, i.e. the perception of mutual relations and impact. New logistics concepts resulting from technological development will be created. One of the new solutions is the concept of Industry 4.0, the implementation of which can generate innovative solutions and long-term effects on the industry, including significantly production logistics.
\end{abstract}

Keywords: logistics, production logistics, Industry 4.0, new technologies

\section{INTRODUCTION}

Many tasks that logistics is facing, combined with global character, are a very important element of modern economy. The need to implement comprehensive and innovative solutions (especially in the aspect of Industry 4.0) appeared through the volatile and dynamic market. Logistics must keep up with and even overtake modern changes in order to satisfy individual customers' needs. Logistic orientation is an important criterion for managing production, commercial and service companies. The idea of logistic management is not to manage separate, individual logistic activities, but to control the entirety of logistic activities of corporations cooperating in supply chains and logistic chains. Logistic management should therefore be treated as a specific approach to the subject of logistics, which these both concepts should not be opposed (Sołtysik, 2003).

\section{PRODUCTION LOGISTICS}

Logistics is a process of physical flow of material goods (materials, raw materials, semifinished products, finished products), (Słowiński, 2008).

Logistic orientation has a character of flow. This means that enterprises are guided in their activities by only important values, processes and logistic factors to ensure effective and efficient flow of raw materials, semi-finished products, final products in the enterprise as well as in supply chains and logistic chains.

We can define production logistics as a subsystem of a logistics' system that accomplishes its tasks or management and activities related to supplying the production process, the flow of goods from their purchase, through production and distribution to the final customer (together with after-sales service) to meet market requirements (Szymonik, 2011).

Production logistics covers all phases of product life (Fertsch, 2005). The first of these is design by examining the level of customer service based on collected information, preparation of the concept of customer service, creation of a logistic system for production supply and customer service. The second phase is the production by the organization of: supply, turnover of materials, packaging, physical distribution of products, storage, after-sales service and servicing, maintenance of production traffic. 
The next phase is the current operation of the product, i.e. supply to exploitative materials, provision and preparation of operating personnel, distribution and storage of manufactured products as well as maintenance and repair services. The last phase of product life is the withdrawal of the product from use by the use of material from the demolition of the product, recycling, the guarantee of proper storage of non-reusable residues formed in the life cycle and also the scrapping of the product.

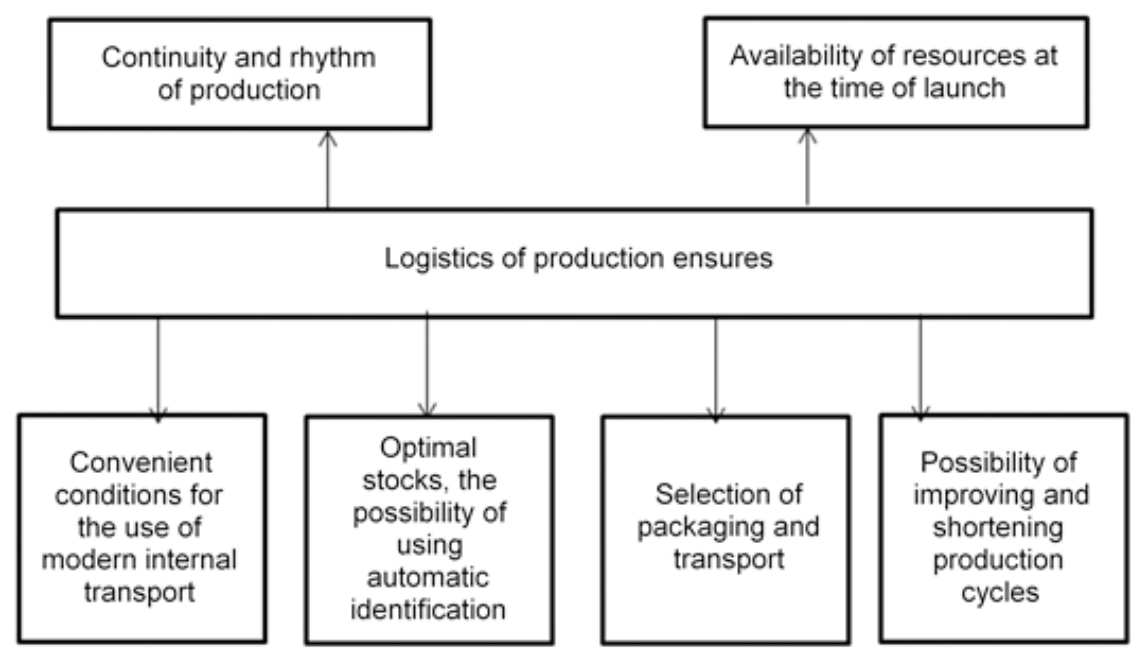

Source: (Szymonik, 2012).

Fig. 1. The aims of production

The goals presented in Figure 1 can be achieved by applying appropriate tools and instruments, such as proper policy, research, using of modern management methods supported by information technologies. Table 1 presents the subsystems of production.

When making decisions about production, solutions within the circulation of information and goods are shaped according to the emerging conditions and needs, including, among others, forecasting demand, product planning, equipment layout, processes design, aggregated planning, production capacity management, warehouse management. Essential problems which solution determines the suitability of some logistic solutions in the production process are (Szymonik, 2012):

- kind of production organisation,

- layout of production circulation,

- product properties (structure, construction, degree of processing, production technology, complexity),

- distribution and location of individual machines involved in the production process,

- ruler of material supply. 
Table 1

Subsystems of production logistics

\begin{tabular}{|c|c|}
\hline Subsystem & Characteristics \\
\hline Management & $\begin{array}{l}\text { Activity and practical knowledge related } \\
\text { with planning and control with the intention to achieve the assumed satisfaction and level of } \\
\text { customer's satisfaction, the proper level of performance, level of costs and profit. }\end{array}$ \\
\hline Production & $\begin{array}{l}\text { Production of products (components, parts, semi-finished products, assemblies, final } \\
\text { products), the term usually refers to the physical operations necessary to create a product. }\end{array}$ \\
\hline Storage & $\begin{array}{l}\text { A group of treatments related to temporary acceptance, storage, handling, completing, } \\
\text { registering, preserving and issuing material goods. }\end{array}$ \\
\hline $\begin{array}{l}\text { Manipulation } \\
\text { of raw } \\
\text { materials }\end{array}$ & $\begin{array}{l}\text { In production logistics, physical functions include changes in the placement of materials in } \\
\text { circulation, from the moment of their acceptance to the moment of their release in the zone of } \\
\text { a specific object. Manipulation includes acceptance, storage, internal transport, packaging, } \\
\text { storage, distribution and release. }\end{array}$ \\
\hline $\begin{array}{l}\text { Circulation } \\
\text { of materials }\end{array}$ & $\begin{array}{l}\text { The way and direction of transport of materials with the order of placing them on the } \\
\text { production line. }\end{array}$ \\
\hline Piloting & $\begin{array}{l}\text { Consolidated set of procedures, reports, data for regulating and planning the supply of the } \\
\text { production line. }\end{array}$ \\
\hline Control & $\begin{array}{l}\text { It includes checking the compliance of the quantity of products with the order and control of } \\
\text { compliance with specification (accompanying document). }\end{array}$ \\
\hline $\begin{array}{l}\text { Diagnostics of } \\
\text { materials } \\
\text { management }\end{array}$ & $\begin{array}{l}\text { Assessment of the efficiency of their management (a note is carried out on the basis of the } \\
\text { material consumption's in production indicator, which presents the efficiency in use of } \\
\text { materials, energy, fuels, dynamics and material inventory levels, stock growth efficiency, unit } \\
\text { consumption of raw materials, rhythmicity, degree of production material utilization. }\end{array}$ \\
\hline $\begin{array}{l}\text { Waste } \\
\text { disposal }\end{array}$ & $\begin{array}{l}\text { Removal, management of post-production, post-production and post-use substances as well } \\
\text { as materials with these of a solid consistency, also liquid (non-sewage), not intended for use } \\
\text { at some place and time, useless at the point of origin and post-use products and disqualified, }\end{array}$ \\
\hline $\begin{array}{l}\text { Rotation } \\
\text { of tools }\end{array}$ & Necessary in the process of production \\
\hline $\begin{array}{l}\text { Supply of the } \\
\text { production } \\
\text { area in media }\end{array}$ & All utilities necessary for production, i.e. electricity, gas, water, liquid fuels, etc. \\
\hline $\begin{array}{l}\text { Post-sale } \\
\text { service }\end{array}$ & Refers to assembly, service, transport and disposal. \\
\hline $\begin{array}{l}\text { Information } \\
\text { management }\end{array}$ & $\begin{array}{l}\text { A set of all elements and relations between them that perform a role in the information flow } \\
\text { process in the production logistics sector. }\end{array}$ \\
\hline
\end{tabular}

Source: (Figurski, 2009, Szymonik, 2012).

\section{MODERN DEVELOPMENT OF LOGISTICS}

The determinants of changes on the global market are presented as "megatrends" of logistics development. They can be defined as permanent economic, social, political and cultural trends. "Megatrends" can be described as permanent economic, social, political and cultural tendencies, phenomena arising in the process of civilizational development of society, determining the main directions and objectives of the prospective development of humanity (Bendkowski and Matusek, 2013).

In the field of logistics, this concept can be defined as the force that changes the functioning of logistic business entities, the way of acting, competing, and the tendency that affects every aspect of the functioning of society and, hence, logistics. "Megatrends" affecting the development of logistics can be divided into two groups: social and economic-technological, in which many elements will penetrate and complement each other by generating feedback (Białasiewicz, 2011). The summary list of global „Megatrends" affecting logistics is presented in Table 2.

The continuous development of logistic concepts is noticeable. The dynamism of processes, the scope and manner of using and implementation of tools resulting from technical and technological development in the sphere of operational, tactical and strategic activities in the local, regional and global perspectives is increasing. Due to this, the modern supply chain is characterized by the ability to react quickly and optimally use the company's resources. 
Table 2

"Megatrends" social and economic - technological affecting the functioning of logistics Social „Megatrends”

Demographic change, population aging, limited availability of qualified personnel

Saturation of already developed markets

Urbanization (the population of cities in the world is systematically growing)

Individualization and expansion of consumer power due to the availability of information

in the net

Migration and Pluralization

(demographic changes also take place

within the working age group, professionally active. As a result of

migration, the structure of this group is a subject of increasing

diversity in terms of culture and language)

Consumerism (turn of societies

towards 24-hour access

to goods, services and consumption)

Conflicts, terrorism, crime

Growing stratification of societies

Changes occurring in logistics and operation and supply chain structures

Source: (Bujak, 2016).

As a result of many changes on the market, new forms, ways and concepts of logistics functioning are being sought that would meet the requirements in the area of meeting customer expectations, increasing competitiveness on the market. The results of the analyses indicate that the development of activities and logistic strategies in Poland is influenced by:

- development of information and communication technologies,

- development of the Cloud and BigData concept,

- building a culture of innovation,

- automation of logistic processes,

- development of the concept of "green logistics",

- development of the Intelligent Transport Systems (ITS) concept

- development of logistics infrastructure.

The indicated solutions have an impact on the development of logistics, but Industry 4.0 deserves special attention.

\section{SUPPLY CHAIN 4.0}

The supply chain is created in every enterprise as a result of the interference of supply, production and distribution spheres. The structure of the supply chain undergoes constant changes under the influence of the market and is an important part in the developed business strategies. The supply chain is closely related to the processes, structure and objectives of the company. The process includes the subject of the flow, the structure concerns the subject structure, while the objectives cover the functional scope, and also contain areas of cooperation of all participating entities. The supply chain includes: raw materials, auxiliary materials and cooperating elements. One definition of the supply chain says that it is an integrated management of logistics flow sequences, processing and handling activities - from suppliers to final customers, necessary to produce a product / service in an efficient and effective way (Kruczek, 2011). The task of logistics is to shorten the duration of processes throughout the supply chain, because it generates financial expenses. The concept of Industry 4.0 with the use of digital supply chains is emerging. In the era of a dynamically changing market, digitization dominates whole logistic industry. The reorganisation of the entire industry in the field of modern methods is not an easy task. The advantage of supply chains based on digitisation is the implementation of prospective methods used in the enterprise. The digital 
direction is able to predict future needs related to the supply chain and thus entrepreneurs can make strategic choices as to the allocation of their resources and the direction of development. The impact of the Internet of Things is crucial, which can be used in digital supply chains. Thanks to this, the entire logistics industry will improve processes, which will reflect on more fluent and more efficient transport of goods and will allow less involvement of company resources. In the logistic industry, the Internet of Things will be used to share and transmit data from multiple sources to numerous devices. This will allow the implementation of technical novelties in many aspects of the supply chain business in terms of management, decision making, loading, final delivery and distribution. Data visualization will enable logistic managers to react faster and provide better information to customers about the company's plans and capabilities.

The pace of implementation of technology related to the Industry 4.0 concept will affect which enterprises on the market will develop, which will suffer losses, and which will turn into potential bankrupts. The benefits related to the use of Industry 4.0 logistics:

- full automation and robotisation of processes,

- increase in the use of fixed assets,

- lower equipment costs,

- reduction of direct labour costs,

- reduction of inventory of activities in progress and production cycles,

- quick response to a variable production task,

- resistance to internal disturbance,

- increase in the quality of manufactured products,

- extension of the production system.

\section{REVOLUTION OF THE INDUSTRY 4.0}

The concept of Industry 4.0 assumes the implementation of new business models and increasing the potential to optimise logistics, which will be used to implement the concept of delivering products tailored to individual customer needs. The foundations of the concept create a tendency related to technological development and networking, which cause changes in the functioning of logistics and the supply chain. Technological innovations make it possible to introduce changes in the organisational cooperation of the supply chain. Examples of Industry 4.0 applications are autonomous vehicles, robots, 3D printing and new materials. The basis for the development is the Internet, the availability of computing power, data collection and processing, and mobile devices. Just like intelligent sensors connected to the Internet, thanks to which we are able to obtain interesting for us data and monitor the course of planned operations or processes. It is possible to implement new business models known as sharing economy, which enable global operations through the use of digital technologies. The main foundations of Industry 4.0 assume new business models and increase the potential to optimise production and logistics, which will be used in accordance with dynamic needs and conditions. The conditions and characteristics of the future production include:

- adaptation of products in high production flexibility,

- involvement of business clients in management processes and creation of added value,

- providing high quality services,

- digitisation of industry,

- creating new business models,

- optimisation of production and logistics.

Industry 4.0 is at a time of great development and will be conducted in various sectors in seven basic directions (Schwab, 2016) presented in Figure 2. 


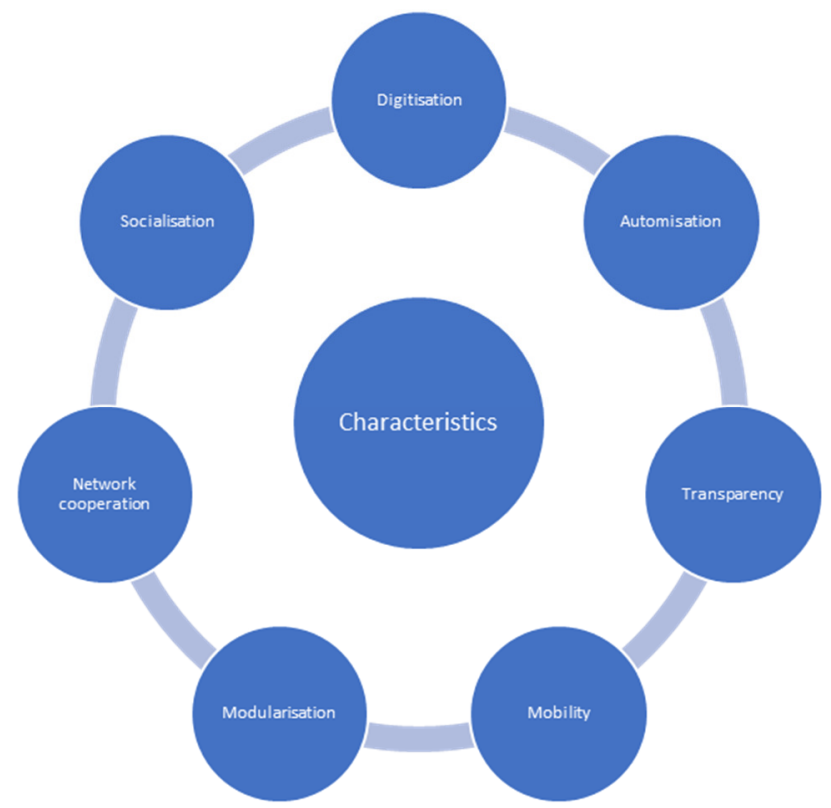

Fig. 2. Seven features most frequently considered in relation to Industry $\mathbf{4 . 0}$ Source: (Bujak, 2016).

Technology connected with the Industry 4.0 concept are interrelated and dependent on each other. The main task is to build such a level of technology cooperation that will allow you to shorten the time to introduce new products to the market tailored to individual customer needs and ensure competitiveness on the market. The main technologies and concepts of Industry 4.0 enable global operations of the company, access to necessary data, remote control over the course of the process and creation of "intelligent" factories that organize the production process and flexibly react to changes. Technological innovation generates big changes, new markets emerge and the way the company operates changes radically.

\section{CONCLUSION}

Industry 4.0 is a great opportunity for the entire European Union, but it will be a complicated process. The whole world is trying to find better and better solutions adapted to the needs of customers and the requirements of the 21 st century. There is no going back from the concept of Industry 4.0. It is necessary to implement new foundations, acquire knowledge and competences related to activities related to the changing market. It is worth pragmatically and creatively appear in Industry 4.0 before it becomes a requirement and a necessity to be able to continue cooperation with those who have implemented or will implement this concept. The time aspect in this case is of great importance. Management strategies in industrial logistics allow to effectively and efficiently manage the flow of products and materials in the company.

\section{REFERENCES}

Bendkowski, J. and Matusek, M. (2013). Logistyka produkcji. Praktyczne aspekty, Volume 2. Gliwice: Wyd. Politechniki Śląskiej, p. 35.

Białasiewicz, M. (red.). (2011). Podstawy nauki o organizacji. Przedsiębiorstwo jako organizacja gospodarcza. Warszawa: Polskie Wydawnictwo Ekonomiczne.

Bujak, A. (2016). Wiodące przekształcenia logistyki XXI wieku. Czasopismo Gospodarka Materiałowa i Logistyka, Volume 5: Wyd. PWE.

Fertsch, M. (2005). Logistyka produkcji. Poznań: Instytut Logistyki i Magazynowania.

Figurski, J. (2009). Ekonomika logistyki. Warszawa: WAT.

Kruczek, M. (2011). Koncepcja diagnozowania w wewnątrzorganizacyjnym łańcuchu dostaw. Gliwice: Zeszyty Naukowe Politechniki Śląskiej, Volume 56, p. 143-155.

Pfohl H. Ch. (1998). Systemy logistyczne. Poznań: Instytut Logistyki i Magazynowania.

Pfohl, H-Ch. (2016). Supply Chain 4.0, Configuration of Cooperative Networks in Disruptive Environments. Polish Logistics Congress 2016: 18th - 20th May 2016, Poznań. 
Schwab, K. (2016). The Fourth Industrial Revolution. Davos: World Economic Forum.

Słowiński, B. (2008). Wprowadzenie do logistyki. Koszalin: Wydawnictwo Uczelniane Politechniki Koszalińskiej.

Sołtysik, M. (2003). Zarządzanie logistyczne. Katowice: Wydawnictwo Akademii Ekonomicznej.

Szymonik, A. (2011). Logistyka i zarządzanie łańcuchem dostaw. Warszawa: Wyd. Difin.

Szymonik, A. (2012). Logistyka produkcji. Warszawa: Wyd. Difin. 